\title{
PROCEDURAL REQUIREMENTS OF A GRIEVANCE ARBITRATION CLAUSE: ANOTHER QUESTION OF ARBITRABILITY
}

RECENT Supreme Court decisions ${ }^{1}$ in the field of labor arbitration call for a reappraisal of existing decisions defining the extent to which courts rather than arbitrators should decide questions involving the procedural requirements of the grievance process. Almost all collective bargaining agreements today provide for arbitration as the last step in the adjustment of grievances. ${ }^{2}$ Two limitations on the arbitrator's power to hear grievances are commonly incorporated into collective agreements. The terms of the arbitration clause in some degree limit the subject matter which the arbitrator can consider. ${ }^{3}$ The arbitration clause also establishes more or less definite procedures which a party wishing to submit a dispute to arbitration must follow. ${ }^{4}$ Both the subject matter and the procedural limitation may be raised defensively, either in an action to compel arbitration or before the arbitrator himself, in an attempt to preclude an arbitral decision on the merits. ${ }^{5}$ When "arbitrability" is challenged in a judicial proceeding, the court must determine how far it can delve into the issue of arbitrability without transgressing on the arbitrator's authority to interpret the agreement. The Supreme Court has substantially clarified this issue recently with regard to subject matter arbitrability. ${ }^{6}$ The role of the courts in determining procedural arbitrability remains unsettled.

The first post-Lincoln Mills ${ }^{7}$ case to deal with a question of procedural

1. United Steelworkers v. American Mfg. Co., 363 U.S. 564 (1960) ; United Steelworkers v. Warrior \& Gulf Nav. Co., 363 U.S. 574 (1960). See also United Steelworkers v. Enterprise Wheel \& Car Corp., 363 U.S. 593 (1960).

2. Ninety-four per cent of collective bargaining agreements provide for arbitration of grievances which arise under them and which the parties are unable to settle themselves. 2 BNA Collective Bargaining Negotiations and Contracts $\llbracket 51: 7$ (1960).

3. Cox, Reflections Upon Labor Arbitration, 72 HARv. L. Rev. 1482, 1509-10 (1959).

4. E.g." "Time limits for a request of arbitration are frequently imposed. These vary widely from a few days to several months." 2 BNA Collective Bargaining NegoriaTroNs AND CoNTRActs $\mathbb{f} 51: 281$ (1959). It is usually required at some point in the grievance procedure that the grievance be put in writing. Id. at $\{51: 21$. "More rarely, some rules may be specified concerning the obligations of the parties with respect to investigations to clear up disputes." Ibid.

5. See Wellington, Judge Magruder and the Labor Contract, 72 HaRv. L. Rev. 1268, 1286-89 (1959).

6. ABA Subcommittee on Labor Arbitration Law, Labor Arbitration in the Federal Courts, 15 ARB. J. (n.s.) 113 (1960); see Hays, The Supreme Court and Labor Law, October Term, 1959, 60 Colum. L. Rev. 901,919 (1960).

7. Textile Workers Union v. Lincoln Mills, 353 U.S. 448 (1957). This decision interpreted $\S 301$ (a) of The Taft-Hartley Act, 61 Stat. 156 (1947), 29 U.S.C. $\$ 185$ (a) (1958), as placing judicial "sanctions behind agreements to arbitrate grievance disputes," 353 U.S. at 456. 
arbitrability was Boston Mut. Life Ins. Co. v. Insurance Agents Union. ${ }^{8}$ The union sought arbitration of its claim that an employee had been wrongfully discharged. It complied with the detailed time requirements set out in the collective bargaining agreement for all steps in the grievance procedure leading up to arbitration. But the agreement set no explicit time requirement for designating an impartial chairman of the arbitration board in the event of disagreement between the parties' representatives. The union waited eleven months. When the impartial arbitrator was finally appointed, the company sought an injunction in a federal district court to prevent arbitration, on the ground that the union had failed to comply with all procedural requirements. ${ }^{9}$ District Judge $W_{y z a n s k i}$ interpreted the collective agreement to the extent of finding an implied requirement that the party seeking arbitration proceed with reasonable speed. Declining to decide the issue of "reasonable speed," he directed the parties "to proceed expeditiously before the Arbitration Board" in order to ascertain whether the union had acted with reasonable diligence. ${ }^{10}$ Reviewing this decision on appeal, the Court of Appeals for the First Circuit looked to principles which it had developed in an earlier case involving subject matter arbitrability. ${ }^{11}$ Chief Judge Magruder declared that when the aid of the court is sought to enforce an arbitration promise, the court has an inescapable obligation to determine as a preliminary matter "whether all the conditions precedent to arbitration have been fulfilled."12 The case was remanded to the district court to make this determination, thus foreclosing to the arbitrator the question of procedural arbitrability. ${ }^{13}$

Boston Mutual was followed by the Seventh Circuit in Brass Workers Union v. American Brass Co. ${ }^{14}$ Article VII of the collective bargaining agreement involved in that case set up the typical three step grievance procedure, added an optional fourth step allowing either party to "call in the U.S. Department of Conciliation," and contained a section stating:

The Company agrees that its action in making discharges for cause or giving disciplinary layoffs, may be reviewed in arbitration, at the request

8. In the Matter of Jacobson, 161 F. Supp. 222 (D. Mass.), rev'd and renanded sub nom., Boston Mut. Life Ins. Co. v. Insurance Agents' Union, 258 F.2d 516 (1st Cir. 1958), 171 F. Supp. 125 (D. Mass.), aff'd per curiam, 268 F.2d 556 (1st Cir. 1959).

9. See $161 \mathrm{~F}$. Supp. at 223.

10. $I d$. at $225-27$.

11. The principles were developed fully in Local 149, Fed'n of Technical Engineers v. General Elec. Co., 250 F.2d 922 (1st Cir. 1957).

12. $258 \mathrm{~F} .2 \mathrm{~d}$ at 522 .

13. Judge Wyzanski found on remand that the union was not guilty of unreasonable delay. 171 F. Supp. 125 (D. Mass.), aff'd per curiam, 268 F.2d 556 (1st Cir. 1959). In view of the appellate court's insistence upon a final resolution of this issue by the district court, the finding of reasonable time would seem to have been the law of the case when it finally reached the arbitrator.

14. 172 F. Supp. 465 (E.D. Wis.), aff'd, 272 F.2d 849 (7th Cir. 1959), cert. denied, 363 U.S. 845 (1960). 
of either party, but such request shall be made in writing within ten (10) days after the Company's final answer in writing to the Union. ${ }^{15}$

The only specific description of the procedure to be followed after a conciliation attempt was contained in article VIII, the general arbitration article, which provided that:

if either party gives notice of taking the matter to the Fourth Step, then arbitration may be appealed within ten (10) days after it is determined that no agreement can be reached by the Fourth Step. ${ }^{16}$

15. Brief for the Appellant, Appendix p. 20, Brass Workers Union v. American Brass Co., 272 F.2d 849 (7th Cir. 1959). The earlier steps in the grievance procedure were described by Article VII as follows:

\section{Grievance Procedure}

Section 1. Should there be any complaint, controversy, or grievance involving the terms of this Contract by an employee or the Union or the Company, the same shall be handled in the following manner:-

1. Between the immediate foreman and the Union Steward in the division.

2. Between the Department Foreman and the Department Committee. At this point, the grievance or controversy shall be reduced to writing on a blank allowing for notations as to action or disposition. Copies of such form properly filled out shall be given to both parties.

3. If the matter is not satisfactorily adjusted within a period of twenty-four (24) hours after it reaches the second step, it may be taken up between the Union Bargaining Committee and the Management of the Company. . . .

4. In the event that the parties are then unable to agree, either party or both parties may call in the U.S. Department of Conciliation.

Section 2. Any employee discharged or suspended for disciplinary reasons shall have the right to appeal to the Company, through the Union Bargaining Committee, for a review of his case, provided that such appeal is presented within five (5) working days after such discharge or suspension. An employee laid off or discharged shall be given a copy of his termination slip, which must show Id. p. $19-20$.

the reason for layoff or discharge.

More than nine out of every ten collective bargaining agreements outline the steps to be followed in adjusting grievances. "Three-step procedures (not counting arbitration) are by a substantial margin the most common, appearing in 38 percent of all contracts." 2 BNA Collective Bargaining Negotiations and Contracts $\llbracket$ 51:4 (1960).

16. The collective agreement also contained a typical subject matter arbitrability clause, although this provision was not in issue in the instant case. See 272 F.2d at 855.

Section 3. Matters to be arbitrated shall be limited to the settlement of specific claims arising out of the interpretation or application of the specific terms and provisions of this Agreement. The Arbitration Board shall have no power to add to, subtract from, or modify any of the terms of this Agreement. No question of a change in the wage scale or differentials shall be subject of arbitration. Before the submission of a grievance or dispute to arbitration, the Company and the Union shall set forth in writing specifically the issue to be submitted to arbitration, and the Arbitration Board shall confine its decision to such issue. It is understood and agreed that only one issue at a time may be arbitrated, unless the parties mutually agree to do otherwise.

Brief for Appellant, supra note 15, Appendix pp. 21-22. 
A dispute arose over the discharge of certain employees, and upon a failure of the parties to resolve the dispute between themselves, the union requested that the company join it in submitting the grievance to the Department of Conciliation. The company refused by letter, stating that it did not consider the discharges "illegal." Nevertheless, the Federal Mediation Service was called in by the union; after contacting the company, however, the Service reported by letter that it had found the company's position "firm." Fifty-three days after the company's letter, and thirteen days after the Service's letter, the union requested arbitration. The company refused to arbitrate, claiming that its letter was a "final answer" under Article VII, or, alternatively, that the Service's letter "determined that no agreement [could] be reached by the Fourth Step" within the meaning of Article VIII, and pointing out that in either case the union's request was late. ${ }^{17}$ In seeking a court order to compel arbitration, the union argued principally that the question of procedural arbitrability was for the arbitrator, not the court, to decide. ${ }^{18}$ The federal district court disagreed, relying on Boston Mutual. ${ }^{19}$ The court then held that the collective agreement imposed specific time requirements as a condition precedent to arbitration, that these terms did not appear "unreasonable or harsh on their face," and that the union had failed to comply. ${ }^{20}$ The Court of Appeals for the Seventh Circuit affirmed, ${ }^{21}$ explicitly approving of and relying upon the decision in Boston Mutual.

Two recent Supreme Court cases dealing with subject matter arbitrability cast doubt upon the correctness of the view taken in Boston Mutual and Brass Workers. The first of these decisions, United Steelworkers v. American Mfg. Co., ${ }^{22}$ reversed a Sixth Circuit decision which had refused to order arbitration of what it deemed a "frivolous, patently baseless" claim. ${ }^{23}$ The Court noted that "when the parties have agreed to submit all questions of contract interpretation to the arbitrator," the court's function is "confined to ascertaining whether the party seeking arbitration is making a claim which on its face is governed by the contract."24 The second of these cases, United Steelworkers v. Warrior

17. Brief for Appellee, pp. 8-9, 15-18, Brass Workers Union v. American Brass Co., 272 F.2d 849 (7th Cir. 1959); see 172 F. Supp. at 469-70.

18. $I d$. at 466-67. Brief for Appellant, supra note 16, pp. 10-17. The union relied on Southwestern New Hampshire Transp. Co. v. Durham, discussed at notes 54-55 infra and accompanying text, Insurance Agents v. Prudential Insurance Co., note 51 infra, and Dunphy Boat Corp. v. Wisconsin Employment Relations Bd., 267 Wis. 316, 327, 64 N.W.2d 866,872 (1954) ("if the original dispute is arbitrable, the merit of the defenses available to the employer are to be considered in the arbitration proceedings").

The union also argued on the merits that the employer's letter was not a "final answer." 172 F. Supp. at 466. Brief for Appellant, supra note 16, pp. 17-19.

19. 172 F. Supp. at 469.

20. Id. at 470 .

21. $272 \mathrm{~F} .2 \mathrm{~d}$ at 854.

22. 363 U.S. 564 (1960).

23. United Steelworkers v. American Mfg. Co., 264 F.2d 624, 628 (6th Cir. 1959).

24. 363 U.S. at 567-68. 
$\&$ Gulf $N a v$. Co., ${ }^{25}$ involved the interpretation of a collective bargaining agreement which contained a general arbitration clause, but which, unlike the agreement in American, also provided that "matters which are strictly a function of management shall not be subject to arbitration."26 When the union charged that contracting out maintenance work constituted a partial lockout in violation of the collective agreement, the company pointed to the "function of management" provision and contended that contracting out fell within this category. ${ }^{27}$ Mr. Justice Douglas, writing for the majority, acknowledged that arbitration is a matter of contract and that a party cannot be required to submit to arbitration any dispute unless it has agreed to do so. ${ }^{28}$ But he also stressed the special nature of the collective bargaining agreement and the appropriateness of its interpretation by the arbitrator. ${ }^{29}$ In an attempt to give weight to this latter consideration, Justice Douglas laid down a rule of construction which would allow judges to find contractual authority for an order to arbitrate without being forced to examine and interpret the collective agreement in detail.

In the absence of any express provision excluding a particular grievance from arbitration, we think only the most forceful evidence of a purpose to exclude the claim from arbitration can prevail, particularly where, as here, the exclusion clause is vague and the arbitration clause is quite broad. ${ }^{30}$

25. 363 U.S. 574 (1960).

26. Id. at 576.

27. See id. at 577 .

28. Id. at 582 .

29. Id. at 578-82. Justice Douglas relied extensively on Shulman, Reason, Contract, and Law in Labor Relations, 68 HaRv. L. Rev. 999 (1955) [hereinafter cited as Shulman], and Cox supra note 3 , in support of his conclusions in this discussion. A general listing of the special characteristics of a collective bargaining agreement, drawn from Justice Douglas's opinion and from the articles, includes:

(1) Whereas in the case of commercial contracts, "arbitration is the substitute for litigation," in the collective bargaining situation, "arbitration is the substitute for industrial strife." 363 U.S. at 578.

(2) The collective agreement is "a generalized code to govern a myriad of cases which the draftsmen cannot wholly anticipate." Ibid., with reference to Shulman 1004-05.

(3) "One unique characteristic (of a collective agreement) is the number of people affected." Cox, sitpra note 3 , at 1490 .

(4) "A collective bargaining agreement also covers a wide range of conduct and an enormous variety of problems." Ibid.

(5) "A labor contract operates prospectively over substantial periods. . . . Not all commercial contracts, but surely those which are most familiar, relate to a single transaction.... Since one can hardly foresee all the problems that will develop in an industrial establishment within even a single year, more scope must be left for decisions made in the course of performing the agreement." Id. at 1491.

(6) "The parties to a collective agreement share a degree of mutual interdependence which we seldom associate with simple contracts. . . . When most parties enter into contractual relationship they do so voluntarily, in the sense that there is no real compulsion to deal with one another, as opposed to dealing with other parties. This is not true of the labor agreement." 363 U.S. at 580.

30. 363 U.S. at $584-85$. 
The Warrior test does not require that the court finally determine arbitrability, but only that the court satisfy itself that the dispute is not unequivocably barred from arbitration. ${ }^{31}$ The Court's attitude suggests that a judicial finding of subject matter arbitrability will not preclude the arbitrator from reaching an opposite conclusion, because presumably the arbitrator will not be bound by the same rule of strict construction. Thus, in Warrior, the dispute went to arbitration because the Court did not regard the employer's interpretation as the only possible reasonable construction of the collective bargaining agreement, but that decision did not foreclose the arbitrator, construing the agreement in greater detail, from agreeing with the employer that contracting out was not a proper subject matter for arbitration.

The role of the courts in determining subject matter arbitrability, as set out in American and Warrior, is decidedly narrower than the role assumed by the Boston Mutual and Brass Workers courts in determining procedural arbitrability. The majority opinions in American and Warrior, however, might be regarded as having no effect on the procedural arbitrability decisions, because many of the reasons stated in the Court's decision seem applicable only to problems of subject matter arbitrability. Justice Douglas reasoned that a federal court should view with suspicion any attempt to entangle it in the construction of "substantive provisions" of a collective bargaining agreement in the name of interpreting the arbitration clause, because construction of substantive provisions "necessarily comprehends the merits" of the dispute..$^{32}$ A court decision on the merits of a grievance dispute, he felt, usurped the arbitrator's function. ${ }^{33}$ Overlap between the merits of the underlying dispute

31. Although Mr. Justice Douglas's opinion required "the most forceful evidence of a purpose to exclude the claim from arbitration" in lieu of an express provision in the agreement, 363 U.S. at 585, Mr. Justice Whittaker, dissenting, pointed out that the union had tried repeatedly, but unsuccessfully, to induce the employer to agree to the inclusion of a provision prohibiting the employer from contracting out work. Id. at 587-88. Since it is difficult to imagine any more forceful evidence of a purpose to exclude such claims from arbitration, what sort of evidence would suffice, absent an express provision, is not clear.

Perhaps management could persuade a court not to order the dispute to arbitration if it could demonstrate that the subject matter of the dispute is ordinarily considered outside the realm of joint union-management action, e.g., the company's financial policies or over its selection of an advertising agency. A slight indication that this may be the sort of evidence which the Douglas opinion had in mind may be gleaned from its reference to the frequency with which "contracting out" is the subject matter of arbitration disputes. 363 U.S. at 584 n.8.

32. United Steelworkers v. Warrior \& Gulf Nav. Co., 363 U.S. 574, 585 (1960).

Mr. Justice Brennan, in his concurring opinion in the American and Warrior decisions, took what was perhaps a narrower view. He noted that were the arbitration clause quite narrow, or the exclusion clause quite specific, a court would be "somewhat freer to examine into the merits," since it then could be inferred that "the parties had manifested a greater interest in confining the arbitrator." United Steelworkers v. American Mfg. Co., 363 U.S. 564, 572-73 (1960).

33. Id. at 569. 
and the question of the dispute's arbitrability is almost unavoidable when subject matter arbitrability is involved. Under the typical arbitration clause limiting the arbitrator to questions involving "interpretation and application" of the collective agreement, ${ }^{34}$ the court must decide whether the agreement contains a provision covering the subject in dispute; once the court has found that the agreement does or does not contain such a provision, it has resolved an issue central to the arbitrator's own decision on the merits. ${ }^{35}$ The arbitrability question in Boston Mutual and Brass Workers, however, involved no overlapping, because the courts' findings on the issue of procedural compliance had no impact on the merits of the underlying disputes.

The Court also stressed the necessity of preserving the arbitrator's function as an adjunct of the collective bargaining process. Mr. Justice Douglas observed that a collective bargaining agreement covers many diverse situations, many people, and extends over a substantial period of time. ${ }^{36}$ The draftsmen of a collective agreement, therefore, must leave gaps to be filled in by reference to the industrial background out of which the agreement arose. ${ }^{37}$ Arbitration, which was described as "part and parcel of the collective bargaining process itself," 38 is the means of resolving these unforeseen problems. ${ }^{39}$ It might be argued that this reason for judicial deference to the arbitrator is also limited to cases involving subject matter arbitrability. Procedural rules for grievance arbitration do not appear to be the kind of provision which must be developed over time through continuing bargaining by the parties. They are rules of organization and orderly conduct, more a matter of convenience than a reflection of the parties' economic relationship. ${ }^{40}$

A third leg of the Warrior decision which also seems inapplicable to procedural arbitrability questions is the Court's postulate that arbitrability is a matter of contract, and that the intent of the parties must therefore be honored. ${ }^{41}$ The Court found it could not decide questions affecting the merits because the very nature of an agreement providing for arbitration as the final step in adjusting grievances makes it inconceivable that the parties intended for a court rather than the arbitrator to pass on the merits. It is less certain, absent a provision allowing the arbitrator to decide arbitrability, that judicial determination of a procedural question violates the parties' intent.

34. See, c.g., the provision quoted in note 15 supra.

35. See Wellington, supra note 5, at 1289; Summers, Judicial Review of Labor Arbitration, 2 Buffalo L. Rev. 1 (1952).

36. See 363 U.S. at $578-80$. See generally note 29 supra.

37. Id. at 580 .

38. Id. at 578 .

39. Id. at 581 .

40. Contra, Cox, supra note 3, at 1510-11.

41. 363 U.S. at 566. Justice Douglas relied on Labor Management Relations Act (Taft-Hartley Act) $\$ 203$ (d), 61 Stat. 154 (1947), 29 U.S.C. $\S 173(d)$ (1958), which states:

Final adjustment by a method agreed upon by the parties is hereby declared to be the desirable method for settlement of grievance disputes arising over the application or interpretation of an existing collective-bargaining agreement. 
There is, however, one important policy underlying the Warrior decision which can be applied to the problems of procedural arbitrability. The Court chose to defer to the arbitrator because, by virtue of his acquaintance with the industry and shop practices constituting the environment in which the collective agreement was drawn up, the arbitrator is better qualified to settle disputes arising under the agreement. ${ }^{42}$ The ambiguous nature of most collective bargaining agreements, the Court reasoned, calls for this industrial expertness to uncover the parties intent. ${ }^{43}$ Procedural provisions can be as vague as those dealing with substantive matters. ${ }^{44}$ They also require interpretation by someone who can look behind the agreement to determine what the parties meant by the term, whether strict application is reasonable in the industrial context, what resolution is most acceptable to both parties, and which interpretation is most suitable to the proper functioning of the arbitral process. The Court's recognition of the arbitrator's special competence must be considered a tenet of national labor policy relevant to the formulation of the federal common law of labor contracts. ${ }^{45}$ As applied to future cases dealing with procedural arbitrability, it would appear to require that courts follow a rule of construction similar to the Warrior rule: unless the meaning and effect of the procedural provision is unequivocal, the court should reserve final determination of these issues for the arbitrator.

It may be objected that the Warrior rule should not be applied to procedural arbitrability cases on the basis of this single policy consideration when the other policies underlying that decision are probably inapplicable to issues of procedural compliance. But the fact that other policies are inapplicable does not mean that such policies call for a contrary result. For example, the observation that the parties' intent is unclear when procedural issues, not touching on the merits of the dispute, are involved does not lead to the conclusion that the parties want a court to decide such issues. It means simply that speculation about the probable intent of the parties gives no guidance at all. In this vacuum, the single policy recognizing the competence of the arbitrator deserves great weight. This is especially true when the question before the court is the adoption of a rule of construction for contracts. Whatever rule is adopted, the parties are not foreclosed from contracting to reach the opposite result. Assuming, as is probable, that the management generally desires judicial determination of arbitrability and the union does not, ${ }^{46}$ the rule adopted is important only to the extent that it re-

42. See 363 U.S. at 581-82. See generally note 29 supra.

43. See 363 U.S. at $579-81$.

44. The "reasonable time" issue in Boston Mutual is a sterling example. See text at notes 8-13 supra.

45. Textile Workers Union v. Lincoln Mills, 353 U.S. 448 (1957), charged the federal courts with the responsibility of fashioning the substantive law to apply in suits under $\S 301$ "from the policy of our national labor laws." Id. at 456 .

46. This would seem to be the case since almost all arbitration claims will be brought by the union. Shulman 1007. The employer will therefore favor the system which puts the 
quires one party to overcome a presumption against its viewpoint by inserting its viewpoint, in explicit terms, in the agreement.

If the Wamior rule were applied to procedural arbitrability cases, the Boston Mutual doctrine would of course be superseded. The entire controversy in that case, including the issue of whether the agreement contained an implied "reasonable time" requirement, would be referred to an arbitral decision. ${ }^{47}$ The result in the Brass Workers case, however, might be reconciled with the Warrior rule, for the court's finding that the procedural provisions involved were unambiguous seems on its face to satisfy that test. ${ }^{48}$

The first post-Warrior decision dealing with procedural arbitrability ignored the Boston Mutual doctrine but in so doing it went even further in deference to the arbitrator than the suggested rule of construction would require. In Philadelphia Dress Joint Bd. of ILGWU v. Sidele Fashions, Inc., ${ }^{49}$ the employer contended that certain grievances were not arbitrable because the union had ignored two of the steps in a three step grievance procedure. The union admitted that it had not taken these intermediate steps, but contended that an act of the company had made these steps impossible and that the attitude of the company had made them futile. The district court noted that the validity of the union's position depended upon facts which the affidavits indicated to be in dispute. ${ }^{50}$ Since the union had moved for a summary judgment ordering arbitration, the court concluded that it would have to deny the motion if the facts in dispute were material to its decision. Summary judgment was granted, on the ground that questions of procedural arbitrability, unlike questions of subject matter arbitrability, were entirely for the arbitrator, ${ }^{51}$ and therefore the disputed facts were not material.

greatest number of blocks in the way of a decision on the merits; with both the trial judge and the arbitrator passing on issues of arbitrability, the chances of avoiding a decision on the merits seem greater. Even if one or the other will decide the question completely, the repute of judges will probably make them seem more favorable to the employer. See Summers, supra note 35.

47. See Wellington, supra note 5, at 1288; Cox, supra note 3 , at 1510 ("It is submitted that both [Boston Mutual] courts erred."). Cox can be interpreted, however, as urging the submission of all procedural arbitrability questions to the arbitrator. See note 51 infra.

48. Whether the court in Brass Workers correctly interpreted the facts to reach this conclusion might be open to dispute. The union could have argued: (1) the issue of whether the company's letter constituted a "final answer" should have gone to the arbitrator (which the union argued implicitly), see note 18 supra, (2) the union "substantially complied" with the requirements of Article VIII, supra note $16,(3)$ the dispute was a "continuing violation," see note 55 infra, (4) the requirements were "promises" rather than "conditions precedent," see note 55 infra.

49. 46 L.R.R.M. 2894 (E.D. Pa. 1960).

50. Id. at 2895-96.

51. Judge Van Dusen pointed to two decisions by federal courts in the eastern district of Pennsylvania as evidence of "ample lower court authority" supporting his position. In both cases, United Cement Workers Union v. Allentown-Portland Cement Co., $163 \mathrm{~F}$. Supp. 816 (E.D. Pa. 1958), and Insurance Agents v. Prudential Ins. Co., 122 F. Supp. 
While the Sidele court's disregard of Boston Mutual seems proper in view of the Warrior decision, its complete abandonment of the procedural arbitrability question to the arbitrator appears contrary to the Supreme Court's decision. The Court pointed out in Warrior that arbitration is a matter of contract and that Congress has assigned to the courts the duty of determining whether the recalcitrant party has breached its contractual promise to arbitrate. ${ }^{52}$ The feeling reflected in this policy seems to be that the parties to a collective agreement should be able to bargain about the circumstances in which arbitration will be invoked, come to whatever agreement on this matter that they find mutually acceptable, and have the terms of arbitrability which they select respected by a court. The Supreme Court restricted this freedom to contract by imposing the requirement of explicitness, but it did not deny the freedom itself. A party may not only wish to preclude arbitration of certain subjects. It may also wish to preclude arbitration of any grievance when certain procedures are not followed in presenting it. It seems logical to conclude, therefore, that the federal courts should enforce this right whether the parties choose to condition arbitration on the subject matter of the grievance or on compliance with procedural prerequisites. The real issue for the court is whether the party wishing to bar arbitration because of procedural noncompliance has succeeded in drafting a procedural provision which satisfies the "explicitness" test of Warrior.

Warrior requires arbitration in every case in which the arbitration clause is susceptible of being interpreted to permit arbitration. A party seeking to have the court rather than the arbitrator decide procedural arbitrability must therefore consider how best to avoid such ambiguities in the agreement. Of course, a court bent on sending a procedural question to the arbitrator will probably have little trouble finding an ambiguity in the relevant clause no matter how well it is drafted. ${ }^{53}$ The Warrior rule of construction is necessarily directed to judicial discretion. But this fact does not undercut the

869 (E.D. Pa. 1954), the federal courts relied on Pennsylvania law to arrive at their decisions. Although he noted "some language used by the Supreme Court in its recent decisions," the judge also noted that the Court had relied on Cox, supra note 3, and quoted the article to his own purposes:

Using the technical language of the law, I suggest that the conventional arbitration clause limiting the arbitrator to disputes concerning "interpretation and application" of the contract reserves the right to a judicial determination upon whether the arbitrator has jurisdiction over the subject matter but that all other questions-procedural, jurisdictional or substantive-are solely within the power of the arbitrator to determine.

Cox, supra note 3 , at 1511 .

52. 363 U.S. at 582. The Supreme Court thus reaffrrmed its holding in Lincoln Mills that such an assignment is implicit in $\$ 301$ (a). See notes 7, 45 supra. But see Textile Workers Union v. Lincoln Mills, 353 U.S. 448, 460 (1957). (Frankfurter, J., dissenting opinion).

53. For an example of courts reaching the opposite result by this type of "interpreting," see Summers, supra note 35 , at 18 . 
importance of careful drafting; it merely recognizes that, particularly in this area, drafting cannot be foolproof.

One ambiguity which might be referred to the arbitrator is the question of whether the party who fails to comply with the grievance procedure forfeits all rights to arbitrate the grievance. In some factual situations, an arbitrator might find that a limited right to arbitration remains despite the noncompliance. For example, in a recent state case, ${ }^{54}$ the collective agreement contained a provision requiring that any claim for its alleged violation must be filed not later than twenty days after the date that the alleged violation occurred or was first known to have occurred. Two employees did not present their claims within twenty days of the initial violation of the agreement. Instead of holding that this noncompliance barred the claim from arbitration, the arbitrators treated each work week as a separate violation, thus allowing the arbitration to proceed but limiting the back pay award to a period within twenty days of the notices. Since permanent changes in working conditions and many forms of employee discipline could also be characterized as "continuing violations," any arbitration provision imposing time requirements might be found ambiguous when the underlying grievance involves such actions. ${ }^{.5}$

Parties may attempt to eradicate this ambiguity by providing in the arbitration clause that arbitration rights are totally forfeited by procedural noncompliance. But there are two basic objections which may prove fatal to the effectiveness of such a provision. First, if a provision of general applicability is used, it would not be difficult for an arbitrator to conclude that the parties could not have intended the severe result to apply in every instance, regardless of the nature of the underlying grievance, the character of the procedural requirement, or the extent of the deviation. ${ }^{56}$ Under the Warrior doctrine, a court need not make the final decision as to whether a clause is in-

54. Southwestern New Hampshire Transp. Co. v. Durham, 102 N.H. 169, 152 A.2d 596 (1959).

55. The "continuing violation" concept has been found useful in antitrust litigation to circumvent statute of limitation problems not unlike the problem in Southwestern. For a recent example, see United States v. E. I. Du Pont De Nemours \& Co., 353 U.S. 586, 597-99 (1957).

Arbitrators might also use a distinction familiar to the common law of contracts to arrive at the same result. The time requirement might be found a "mere promise" rather than a "condition precedent." See generally 3A CoRbin, Contracts $\$ 633$ (1960). If the arbitrators in Southwestcrn New Hampshire treated the time requirement as a "promise," they would have allowed the company damages, by way of recoupment against the amount the claimants would have recovered had their notice been timely. Recovery would be the same, since the employer's damages would be the amount for which he became liable beyond twenty days.

56. An example of such a situation is Livingston v. Tel-Ant Electronic Co., 23 LAB. ARB. KEP. 672 (N.Y. Sup. Ct. 1955). The collective agreement there contained a requirement that notice demanding arbitration must be submitted to the other party within 24 hours "after written notice has been given by either side to the other of the inability to adjust." It also contained a "time is of the essence" clause. The employer, demanding ar- 
applicable to a given case in order to send the procedural issue to arbitration; it need only conclude that the clause is capable of being found so. Parties would be well advised, consequently, to make explicit their intention by relating the loss of arbitration rights to noncompliante with specific procedures established for specific types of grievances. When a court is faced with a specific provision, related to a particular type of grievance, which makes compliance with certain procedural requirements an absolute prerequisite to arbitration of that type of grievance, the court's respect for the intent of the parties will probably make it reluctant to recognize the possibility that such a clause will be found unduly harsh. ${ }^{57}$

Even if the collective bargaining agreement succeeds in making explicit the parties' intention to bar arbitration, a court must still order arbitration if it finds a possibility that the noncompliance could be excused, usually by the behavior of the other party. ${ }^{58}$ This was the issue in the Sidele case. The union's affidavits alleged that it was justified in ignoring two intermediate steps of the grievance procedure because the company had made these steps impossible and futile. The district court refused to consider this issue, referring it entirely to the arbitrator as the proper tribunal to make the decision. Under Warrior, however, a narrower rationale was available. The possibility that an arbitrator would find this a valid excuse for the union's noncompliance would have constituted sufficient grounds for ordering arbitration. Of course, some excuse can be offered for every failure to comply with procedural requirements. To prevent complete abdication to the arbitrator on procedural issues, a court will have to make a threshhold determination that the excuse offered is tenable, refusing to order arbitration when it is not.

bitration, failed to meet the twenty-four hour requirement. Passing on the procedural objection, the court said,

I am of the view that under the circumstances of this case, the strict limitation of twenty-four hours is unreasonably harsh and, in my opinion, unenforceable. It seems to me that the employer here acted as expeditiously as possible.

Id. at 674 . The time requirement in this case was probably included in the collective bargaining agreement to expedite the processing of the ordinary grievance involving employee claims against the company. It is arguable that the parties did not intend it to apply to the type of dispute involved in the case.

57. Corbin describes the way courts have handled apparently harsh conditions precedent in ordinary contract situations:

The courts do not hold such express conditions to be contrary to public policy, however; they are not yet ready to limit our much prized freedom of contract so greatly. Nevertheless, they are very ready to put an interpretation on a contract so as to avoid a harsh condition.

3A Corbin, Contracts $\S 748$ (1960). By tying specific procedures to particular types of grievances, the scope for interpretation is narrowed.

58. A typical excuse might be waiver of the time requirement or some formality. See Cox, stipra note 3, at 1511 . 